\title{
Lyrics Videos to Ease the Pronunciation Problem of Indonesian EFL Learner
}

\author{
${ }^{1}$ Dewi Rohmawati \& ${ }^{2}$ Tono Suwartono \\ Universitas Muhammadiyah Purwokerto \\ ('dewyrohmawaty@gmail.com, ${ }^{2}$ suwartononewton@gmail.com)
}

First Received: 8-3-2019

Final Proof Received: 29-5-2019

\begin{abstract}
Pronunciation is a basic for speaking skill. Rare in Senior High School, neither the teacher pay attention with the students' pronunciation skill nor give them such media. This study was intended to investigate the effectiveness of lyrics video for teaching English pronunciation in Senior High School. This was quasi experimental study and the population was the second grade students. Reading aloud was given to the students as the pronunciation test. Their voice was recorded while they did the test. Since it was subjective test, so that inter-rater is used to avoid subjectivity in getting students' score. The score was analyzed using T-test. In the end the result revealed that t-value (2.05) was higher than statistical value of $t$-table (1.676) at the significant level 5\%. Therefore, the students who were taught using lyrics video of English song had better achievement in pronunciation rather than those who were not taught using lyrics video of English song.
\end{abstract}

Keywords: pronunciation; problem; lyrics video; ease.

Pronunciation is a study of how a language is pronounced. According to Bull (2009, p. 352), pronunciation is the way in which a language or a particular word or sound is spoken. It does not have to be exactly the same as native English, but at least students can pronounce like native English. Native English itself sometimes does not have the same pronunciation. This is due to various things such as social surroundings. As stated by Jones (1987, p.11) no two persons of the same nationality pronounce their own language exactly alike. The differences may arise from variety of causes, such as locality, social surroundings, or early influences, and there are often individual peculiarities which are difficult or impossible to account.
Learning pronunciation is an important thing for language learner. The use of language is to communicate. The main goal of teaching language is to make the students able to communicate orally with the target language. The expected outcome of language teaching is students able to understand and use the language outside the classroom.

There are six techniques to teach pronunciation, those are drilling, minimal pairs and related activities, pronunciation and spelling activities, taping students' English, listening activities, and the last is reading activities (Kelly, 2001, pp. 15-22). In this study, two activities were combined to teach pronunciation. Those activities were listening and reading aloud. It means the students have 
to listen to the song while reading the lyric video. They have to imitate the way the lyric is pronounced by listening to the song.

It is believed that listening and pronunciation had a relationship. As stated by Lane $(2010$, p. 1$)$, pronunciation is intimately linked to other oral/aural skills, both influencing and influenced by listening comprehension \& fluency.

To attract the students' attention in the learning process, media is used. It is because teacher as facilitator must be brave to try something new for creative learning (Suwartono, 2006, p. 43). Media is everything which can be used as tool and facilitate the teaching learning process to get its goal (Manik, 2015). There are three kinds of media. Arsyad in Manik (2015) said that those three kinds of media are visual media, audio media and audio visual media. Visual media means that the media can only be seen. Audio media means that the media can only be heard. Audio visual media means that the media can be seen and heard.

In this study, song is used as the media. As stated by Suwartono (2014) all features in songs may support the learning process. All language skills (listening, reading, writing, and speaking) can be taught using songs. Moreover as stated by Kramer in Manik (2015), song are good to introduce supra segmental phonetics. Therefore, song was provided as learning media. The witer was not using song in the form of MP3 but in form of MP4 or video, specifically lyrics video is used. Lyrics are the words of a song (Bull, 2009, p. 264). In other words, lyrics video is a music video that focuses on showing the lyrics of the song on screen as the song played. People who use lyrics video of English song can easily read the english word by imitating the pronunciation through listening the songs.

The benefit of using video in learning pronunciation is that video has pause button. The pause button may help people who use lyrics video to stop the video when they want to read or pronounce the lyrics. When they are not sure about the pronunciation they can repeat the part as often as they want easily. Lyrics video of English song is easy to be found on the internet especially in Youtube.

Song itself has some genre, such as pop, hip-hop, metal, rock and so on. In this study, pop song was used as the teaching media. It was because pop song is the most appropriate genre for educational environement. Most of pop song are also easy listening for the students. Easy listening song may make the students feel comfortable and attract the students to play the music again and again while imitating the song. It is good for English learning to imitate English sound. According to Ramelan (1985: 10), through imitation, much practice and repetition, however, the student will ultimately succeed in producing the foreign sound correctly as the native speakers. Feeling comfortable is an important thing in studying foreign language, so the target of study were made comfortbale first before pushed them to study English.

There are many english songs which can be used as teaching media. There were three songs used to treat the experimental group. Those three songs entitle "Locked Away" sung by R City featuring Adam Levine, "Love You Like a Love Song" sung by Selena Gomez, and "Because Of You" sung by. Those songs were chosen because they are suitable with the syllabus.

Problem of this study is "Is lyrics video of English song effective for teaching English pronunciation to the Second Grade students of SMA Negeri Patikraja in the academic year of 2018/2019?". To answer the problem, the study was conducted in SMA Negeri 1 Patikraja in January 2019.

\section{Method}

This study was conducted to recommend an alternative way for the teacher to teach pronunciation. The population of study was the second grade students of SMA Negeri Patikraja in the academic year of 2018/2019. 
The study used English song to teach English pronunciation. Specifically lyrics video was used as the media. This media will not make the students easily bored in studying English pronunciation. Besides that, this media can also be used by the students outside the school by using smartphone or laptop. It was believed that by seeing and listening lyrics video of English song while imitating the lyrics would make students in senior high schools have a better English pronunciaion.

The aim of this study was to know whether lyrics video of English song effective or not for teaching english pronunciation to the Second Grade students of SMA Negeri Patikraja in the academic year of 2018/2019.

This study is considered as quasi experimental study. Since it used the existing classrooms, the nonequivalent control group design was used. When we used the design, subject may not even be aware that they are involved in a study. It becomes the advantage of the design (Gay, 1987, pp. 289-290).

In getting the sample, pre test was given to all the population. The pre test was used to find out the two classes which have the closest average score. In the end those two classes become experimental and control group. As mentioned by Gay (1987, pp. 289), the more similiar the groups are the better, it is a must to make every effort to use groups that are as equivalent as possible.

There are threeways totest pronunciation ability. Those are limited response, multiplechoice hearing identification, and reading aloud (Madsen, 1983, pp. 59-69). In this study, reading aloud was chosen as the method to test the students' pronunciation skill. There are 20 sentences in 20 numbers which have to be read by the students as the test. The students were tested one by one. While the students doing the test or read the sentences, their voice were recorded. In the beginning pre-test was given to all the population (second grade students of SMA Negeri 1 Patikraja in the academic year 2018/2019 and post-test given to the experimental and control class in the end (XI MIPA 4 and XI IPS 3).

After collecting the data, the data was analyzed. There were some steps to analyze the data before the result was concluded. The first step was scoring the individual test. Inter-rater reliability was used because pronunciation test is a kind of subjective test and the researher want to avoid subjuctivity in giving the score. The second step was finding the mean of experimental and control group. The third step was processing the data using the t-test formula. T-test formula is used in experimental study to compare the experiment group and control group. As stated by Suwartono (2014, pp. 98), t-test is the process of data processing with statistical tools intended to compare two groups of data. The effect of treatment can be seen from the results of the t-test. The last step was finding the degree of freedom to find the value in $t$-table which compared with the result of $t$-test.

\section{Results and Discussion}

The In collecting the data, pre-test was given to all the population. It was done to find out the two classes which have the closest average score. The population in this study were XI Grade Students of SMA Negeri 1 Patikraja in the academic year 2018/2019. The amount of the population were 237 students which divided in 8 classes.

After doing the pre-test, 2 classes was found. Those classes have the closest average score,

Table 1. Pre-Test Score Distribution

\begin{tabular}{llcc}
\hline No & Class & Average Score & N of Test Takers \\
\hline 1 & XI MIPA 1 & 56,76 & 28 \\
2 & XI MIPA 2 & 59,93 & 26 \\
3 & XI MIPA 3 & 60,47 & 28 \\
4 & XI MIPA 4 & 57.87 & 25 \\
5 & XI IPS 1 & 65.60 & 25 \\
6 & XI IPS 2 & 53.04 & 23 \\
7 & XI IPS 3 & 57.14 & 27 \\
8 & XI IPS 4 & 54,11 & 28 \\
\hline
\end{tabular}


those are XI MIPA 4 as the experimental group and XI IPS 3 as the control group. The distribution of pre-test score described in the Table 1.

After the pre-test, two classes which had closest class average score was found, different treatment were given to those two classes as the experimental class and control class. The treatment was done in 3 meetings. While the control class was taught by using lyrics video of English sing, the control class was only taught by using hand book which owned by every student. In the end, post-test was given to know the effect of treatment for both classes. The result of post-test in experimental and control class was different. The comparison of the result can be seen from the Figure 1.

From the data shown in Figure 1, it can be seen that the experiment class had a significant improvement. The control class also had an improvement but not as good as the experiment class. It can be seen that experiment class got 57,87 as the class average score in the pre-test and 75,1 as the class average score in the post-test. In the other side, the control class which got 57,1 as the class average score in the pre-test, in the post-test the class average score was only 67,26 .

After pre-test and post-test score were gotten, those score processed by using independent $t$-test formula. The result of $t$ value was 2,05 with degree of freedom (d.f.) was 50 . In this study, $5 \%$ was used for the

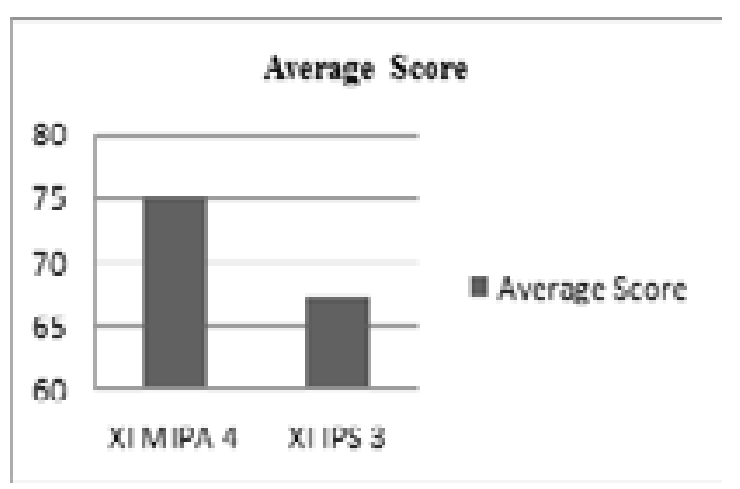

Figure 1. Results Comparison significant level. It can be seen in the t-table, critical value with degree of freedom (d.f.) 50 and $5 \%$ for the significant level was 1,676 . So, it can be concluded that $t$ value was higher than the critical value of $t$ table and Ha or hypothesis was accepted. In other words, the students who were taught by using lyrics video of English song got better achievement in pronunciation skill rather than the students who were not taught using lyrics video of English song. It showed that lyrics video of English song was effective for teaching English pronunciation in the second grade students of SMA Negeri 1 Patikraja.

In teaching and learning process, it is important for teachers to make students able to pronounce English word correctly. By mastering pronunciation, the students will get a better understanding when they study listening or speaking. The teacher can use lyrics video of English song to encourage the student pronunciation ability. Moreover, by hearing the song, the students will feel relax and happy in studying English.

\section{Conclusion}

From the data analysis, it showed that teaching pronunciation by using lyrics video of English song is appropriate to be implemented in the classroom. In this study, the students' average score of post-test in experimental class $(75,1)$ was higher than pre-test $(57,87)$. From the data analysis, the test hypothesis was determined by $\mathrm{t}$-test $\left(\mathrm{t}_{0}\right)>\mathrm{t}$-table $\left(\mathrm{t}_{\text {table }}\right)$ in significance 0,05 or $5 \%$. Thus, the value of the $t_{0}$ was 2,05, while the value of ttable with degree of freedom (d.f.) 50 in the significance $5 \%$ was 1,676 . Therefore, $t_{0}$ score was higher than $t_{\text {table }}$ score obtained from the result of calculation, so the hypothesis was accepted. It means that there was significant difference between students' achievement in mastering pronunciation which was taught by lyrics video of English song and without lyrics video of English song. 
Based on the statement before, lyrics video of English song is effective to improve students' pronunciation mastery at the second grade students of SMA Negeri 1 Patikraja.

\section{References}

Bull, V. (2009). Oxford Learner's Pocket Dictionary. Oxford: Oxford University Press.

Gay, L. (1987). Educational Research. Columbus: Merrill Publishing Company.

Jones, D. (1987). An Outline of English Phonetics. Harlow: Pearson Education Limited.

Kelly, G. (2001). How to Teach Pronunciation. Harlow: Pearson Longman.

Lane, L. (2010). Tips for Teaching Pronunciation. New York: Pearson Longman.

Madsen, H. S. (1983). Techniques in Testing. New York: Oxford University Press.

Manik, S. (2015). Improving Students' Pronunciation Mastery by Using English Songs. The Explora Journal, 1(2). Retrieved from https://uhn.ac.id/content. php?ref=TXgL\&ssid=12_171207095933

Ramelan. (1985). English Phonetics. Semarang: IKIP Semarang Press.

Suwartono, T. (2014). Dasar-Dasar Metodologi Penelitian. Yogyakarta: CV Andi Offset. 